\title{
Article \\ Philology, or the art of befriending the text
}

\author{
Ika Willis \\ School of the Arts, English, and Media, University of Wollongong, Wollongong, \\ Australia.
}

\begin{abstract}
This essay examines the 1960s/1970s' transformation of the text as an object of reading, and argues for an equivalent transformation of philology as a practice of reading. I focus on the oscillation between reading as literacy (the capacity to recognize and decipher a given language) and reading as interpretation (the capacity to respond to the text). This oscillation itself results from an irreducible ambiguity in the text: both a stable verbal artifact with a determinable form and a bearer of indeterminate meaning. Reading Roland Barthes's critique of philology and Ursula Le Guin's science-fictional paean to its possibilities ('The Author of the Acacia Seeds'), I argue for a philological practice that resists, questions, and repositions the closure of the text.
\end{abstract}

postmedieval: a journal of medieval cultural studies (2014) 5, 486-501. doi:10.1057/pmed.2014.30

In this issue of postmedieval, Sheldon Pollock recapitulates the definition of philology he first put forward in 'Future Philology?': 'the discipline of making sense of texts' (see also Pollock, 2009, 937). My paper attempts to unpack this dense, deadpan definition by investigating what it might mean to make - to produce or create - sense out of texts, and whether 'philology' can indeed gather and name all the processes involved in the making of sense. Pollock's definition radically and polemically expands the reach of philology to encompass the whole field of interpretation - all the operations by which marks on a page, or 
soundwaves hitting the ear, or other signs, are turned into sense by a reader, listener, or viewer. We necessarily perform these multilayered and complex operations of sense making whatever we are reading, from fifth-century Sanskrit drama to today's news. Philology and reading thus become more or less coterminous.

I find Pollock's expansive definition of philology both valuable and exciting liberating, indeed. Part of its value lies in its refusal to differentiate between literacy in a given language and the higher-level interpretative operations involved in making sense of a text. ${ }^{1}$ This refusal also involves not differentiating between a text as a verbal artifact (requiring nothing more than simple literacy to be read) and a text as the bearer of meaning (requiring interpretation). Pollock clarifies this point in his critique of De Man in 'Future Philology.' De Man posits the possibility of a text that can be read without producing meaning and a philology that consists of this 'mere reading' (De Man, 1986, 23, cited in Pollock, 2009, 947). Against this idea, Pollock writes:

Even less sensible is positing the existence of a text prior to the meaning it produces, as de Man sought to do in promoting what he called 'philology' over criticism and humanism. What mode of existence does a text have for us when it has no meaning, when it means nothing to us?

$$
\text { (Pollock, 2009, 957) }
$$

A text does not exist as a text unless and until it has meaning to a reader, unless and until its reader can make sense of it. Reading without making meaning is not possible.

Pollock's argument, as I see it, hinges on an oscillation between the idea of 'reading' and the idea of 'making sense,' or perhaps on an ambiguity in the idea of reading as the making of sense. We assume that one is only able to read texts, or to 'make sense' of them, if one has a particular set of skills or literacies appropriate to the text. But does the text dictate which literacies are required to make sense of it? Not necessarily, if literacy cannot be strictly differentiated from the other interpretative operations involved in 'making sense'; if 'making sense' is genuinely a productive activity; and if, as Pollock argues, 'there can be no such thing as an incorrect interpretation' (Pollock, 2014). The question that Pollock's redefinition of philology both solicits and leaves open is: how are we to decide which literacies, which interpretative techniques, should be brought to bear on a given text? If there is no such thing as an incorrect interpretation, is there, finally, such a thing as an inability to read?

A paradigmatic response to this question can be found in Francoise Wacquet's Latin, or the Empire of A Sign. Waquet reads a moment in Pierre Jakez Hélias's memoir of his 1920s Breton childhood, Le cheval d'orgueil. Hélias writes that 'ce latin, qui règne d'un bout de la messe à l'autre, il est pour nous le "breton du dimanche", ['Latin, which holds sway from one end of Mass to the other, is for
1 The thrust of this paper is that 'simple literacy' (like 'the text itself') does not exist, although I will sometimes write as if it does for efficiency's sake. 
us "Sunday Breton"'] (Hélias, [1975] 1995, 132; my translation). He tells how he and the other children made sense of this unfamiliar language:

Nous essayons de ramener ce breton de messe à notre breton de tous les jours grâce à quelques mots qui surnagent sur la musique latine et qui nous semblent être des nôtres. C'est ainsi que nous donnons notre assentiment total au Dies irae, dies illa. En breton, diêz veut dire difficile et nous sommes bien d'accord: tout cela n'est pas aisé, on a bien raison de répéter le mot ... Nous chantons le Kirie eleison avec ferveur ... Et cependant nous nous demandons ce que viennent faire toutes ces charrettes dans la célébration de la messe. C'est que nous entendons dans nos oreilles Kirri eleiz 'so (il y a des tas de charrettes) sans jamais voir la couleur d'une seule d'entre elles. (Hélias, [1975] 1995, 133; cited in Waquet, 1998, 128)

['We ... try to link this church Breton with our everyday Breton through the occasional words floating on the Latin music that seem to be our own. That is why we give our total assent to the Dies irae, dies illa. In Breton diez means difficult and we quite agree: all this is far from easy, we have every reason to repeat the word ... We sing the Kyrie eleison with great fervour ... But we still wonder what all those carts have to do with the celebration of mass. Our ears hear Kirri eleiz 'so (there are heaps of carts), but we never see the colour of a single one.'] (Waquet, 2001, 104-105)

Traditionally, a philologist would see Hélias's response to the Mass as a simple incapacity to read. Undeniably, Hélias and his friends do fail to register the otherness of the language. But they do not fail to make sense of the text: as Waquet points out, they succeed in 'traduisant dans des mots intelligibles une réalité que la barrière linguistique ... transformait en de pures manifestations sonores' (Waquet, 1998, 128) ['translating into intelligible words a reality whose literal meaning the linguistic barrier has ... transformed into mere sounds' (Waquet, 2001, 104)]. Some might see this Latin-Breton translation as just the kind of 'simple ... error' that Pollock invokes in suggesting that 'not all interpretations are worthy of philological attention to the same degree' (Pollock, 2014). I see it rather as a limit-case, capable of clarifying our notions of reading and of 'making sense.' Pollock argues that all interpretations are worthy of attention to the extent that they 'tell us about the text and the properties the text possesses that might have prompted this or that interpretation' (Pollock, 2014). Hélias's reading has little to tell us about the properties of the Latin mass (although, as Sarah Kay pointed out in her response to this paper at the conference 'Philology/Humanism' at Dartmouth College in October 2013, it may tell us about Hélias's fantasies: about peasant apprehension of the world as concrete rather than abstract and about his not being in need of divine mercy [Kay, 2013]). It has a great deal to tell us, however, about 'the text' conceived abstractly, as the disciplinary object of philology. 
In its detailed narration of a concrete practice of making sense of a text that one cannot read, this example exacerbates to the highest degree possible the ambiguity in the idea of reading as making sense of a text. This ambiguity arises directly from a doubleness or split in the nature of the text as a meaning-bearing object: meaning is both an indissociable property of a sign and a new artifact created by the productive activity of a reader. Hélias's account of 'hearing' the Latin Mass in Breton takes the difference between these two meanings to an extreme: as a sign in the system of the Latin language, the word dies does not mean 'difficult'; to Hélias and his friends, it does. This discrepancy poses sharply the question of the relationship between the text understood as a stable verbal artifact (a language with a fixed and knowable set of conventions) and the text as a bearer of meaning (requiring interpretation and producing multiple - even conflicting - senses).

These texts - verbal artifact, bearer of meaning - are neither one nor two: they can neither be entirely conflated nor be entirely distinguished. The history of philology can be understood as the history of negotiating with this irresolvable ambiguity at the heart of its object, the text. This essay examines one particularly transformative moment in the history of philology in the Western world: the 1960s and 1970s. The work of the Tel Quel group in this period resignified the very word 'text,' thereby (at least potentially) transforming the disciplinary object of philology. At the same time, postcolonial studies and the second wave of feminism also began transforming the relationship between texts and sense-making practices. Textual studies have absorbed the transformations of the 1960s/70s thoroughly, but not always consciously, and hence not always effectively ('the more present to our consciousness this discipline of sense making becomes, the more effective it becomes' [Pollock, in this volume]). In this essay, I return to the moment of transformation in order to make present to our consciousness what was at stake then, and now, in making sense of a text.

One elegantly simple, but ultimately untenable, solution to the text's ambiguity proposed in the 1970s is George Steiner's After Babel. Steiner resolves the problem by wholly conflating the text as bearer of meaning with the text as verbal artifact, arguing that reading as 'making sense' simply is literacy. Texts from different historical periods are already in different, self-contained languages. As soon as there is a temporal gap between text and reader 'it is, literally, as if a language had been lost' (Steiner, 1975, 15). An English word whose meaning has changed between the moment of the text's production and the moment of its reception should be understood not as the same word appearing in two different contexts, but as a homonym or 'false friend' in a different language:

The time-barrier may be more intractable than linguistic difference.

Any bilingual translator is acquainted with the phenomenon of 'false 
2 Borges' narrator writes: 'El texto de Cervantes y el de Menard son verbalmente idénticos, pero el segundo es casi infinitamente más rico' (Borges, [1939] 1999, 52); ['The text of Cervantes and that of Menard are verbally identical, but the second is almost infinitely richer'] (Borges, 1962, 52). For readings of Borges's story as a contribution to literary theory, see Bauman (1978) and Martindale (1993). friends' - homonyms such as French habit and English habit which on occasion might, but almost never do, have the same meaning, or mutually untranslatable cognates such as English home and German Heim. The translator within has to cope with subtler treasons. (Steiner, 1975, 28)

Specialist vocabularies (such as those of falconry or navigation) are also troped as languages (Steiner, 1975, 25), and the historical-contextual materials to which Steiner's reader turns in order to situate a text and produce a reading of it are figured as 'dictionaries' or 'glossaries' (Steiner, 1975, 24). Historical context is not 'context' as opposed to 'text'; rather, Steiner writes, 'a text is embedded in specific historical time' (Steiner, 1975, 24), so that 'if they occur in temporal sequence, no two statements are perfectly identical' (Steiner, 1975, 18). Steiner, like the unnamed narrator of Borges's 'Pierre Menard, autor del Quijote,' posits the possibility of the existence of two texts that are verbalmente identicos ['verbally identical'] but nonetheless different (Borges, 1962, 52; Borges, [1939] 1999, 52). ${ }^{2}$ Given words in a given order, written in the 1600 s, comprise a different text, in a different language, from the same words in the same order written in the 1930 s.

Steiner attempts to minimize the degree to which the meaning of a text is seen as depending on extratextual factors, especially the reader's activities. In this way, he is able to circumscribe and legitimate the sense that a reader makes of a text by identifying it with the indissociable meaning of a sign within a language, understood as a stable and total system. The multiplicity of meanings (including historically differentiated meanings) that a word can bear is exorcised from within the word, recast instead as a multiplicity of languages: there are not many possible meanings within one word but many homonyms in different languages. Steiner thus attempts to close the gap between literacy (being able to read a language) and interpretation (making sense of a text) by redefining interpretation as literacy in a historically embedded language, so that interpretation has the certainty and determinability of signification itself. For Steiner, then, all misreadings work like Hélias's misreading of Mass: all misreadings stem from illiteracy; they are failures to identify and understand the 'language' in which a text is written.

Attempts like Steiner's to use the alleged fixity of linguistic meaning to circumscribe textual meaning were the target of Roland Barthes's work with the Tel Quel group in the early to mid-1970s. Through this work, as demonstrated by John Mowitt in Text: The Genealogy of an Antidisciplinary Object, the nature of the text as a disciplinary object was transformed. This transformation centered on the interrelated questions of the text's closure and of the relationship between the text's more or less fixed material-verbal form and the meaning produced by a reader (the sense made of a text). The shift is troped by Barthes and others as the move from the 'philological text' to the 'semiological text.' Here, then, we return to the question of what the word philology names. 
The Tel Quel group was attempting to formulate a new critical theory and practice of reading. Barthes, at least, found that he was unable to do so without constructing a new object: the text:

Pour qu'il y ait science nouvelle, il ne suffit pas en effet que la science ancienne s'approfondisse ou s'étende ... il faut qu'il y ait rencontre d'épistémés différentes ... et que cette rencontre produise un objet nouveau (il ne s'agit plus de l'approche nouvelle et d'un objet ancien); c'est en l'occurrence cet objet nouveau que l'on appelle texte.

$$
\text { (Barthes, [1973c] 1994c, 1679-1680) }
$$

'For there to be a new science it is not enough, in effect, for the old science to become deeper or wider ... there has to be a meeting of new epistemes ... and this meeting has to produce a new object (it is no longer a question of a new approach to an old object): in the event it is this new object that we call text.' (Barthes, [1973d] 1981, 35)

This new object, however, has the same name as an old object - indeed, the same name as the old object against which it defines itself. In Barthes's essay, the new object, 'text' (the semiological text), is defined in opposition to the philological text. The use of the same word for the two different objects is a new strategy for Barthes. Two years earlier, in De l'oeuvre au texte ['From Work to Text'], he had differentiated the objet nouveau [the 'new object'] (Barthes, [1970a] 1994b, 1211), the text, from the work, with philology on the side of the work (oeuvre) (Barthes, [1971b] 1989a, 58; Barthes, [1971a] 1994b, 1213). There is, then, something strategic at stake in the move to name both the old and the new object by the same word, 'text.' 3 This strategy could be seen as performative, in that it calls attention to the irreducible possibility of doubled (or plural) meaning that, as we shall see, distinguishes the semiological from the philological.

Barthes explains the difference between the semiological and the philological text most clearly in his 1973 entry in Encyclopaedia Universalis, Texte (théorie $d u$ ) ['Theory of the Text']. He argues that l'ancien texte des philologues ['the old [text], that of the philologists'] (Barthes, [1973d] 1981, 34; Barthes, [1973c] $1994 c, 1678$ ) conflates the stability of the text as meaning bearer with the fixity of the text as verbal artifact:

l'exactitude littérale de l'écrit ... se confond métonymiquement avec son exactitude sémantique: dans l'univers classique de la loi du signifiant, se déduit une loi du signifié (et réciproquement); les deux légalités coïncident, se consacrent l'une l'autre: la littéralité du texte se trouve dépositaire de son origine, de son intention et d'un sens canonique qu'il s'agit de maintenir ou de retrouver. (Barthes, [1973c] 1994c, 1678)

['the literal exactitude of the written ... is metonymically confused with its semantic exactitude. In the classical universe, a law of the signified is
3 For a lengthy discussion of the implications of the two texts in the work of the Tel Quel group at this period, see Mowitt's discussion of Ducrot and Todorov's 1972 Encyclopedic Dictionary of the Sciences of Language, in which there are two entries for 'text' (Mowitt, 1992, 3-10). 
deduced from the law of the signifier, and vice versa. The two legalities coincide, and each confirms the other: the literality of the text is made the repository of its origin, of its intention, and of a canonical meaning, which has to be maintained or rediscovered.'] (Barthes, [1973d] 1981, 33)

In 'l'univers classique,' the possibility of a single correct interpretation of a text is founded on a metonymic confusion with the possibility of a single correct restoration of the literal, written text. Making sense of a text thus appears naturally coterminous with reading that text according to the 'law of the signifier,' which inexorably chains a signifier to its singular and stable signified, such that a single 'canonical' meaning can be determined for any given text. Barthes's philological text coincides exactly with Steiner's conception of the text as the bearer of a single meaning that can be securely determined with reference to dictionaries and glossaries.

As a result of this conception of the text, Barthes argues, philologists understand it as constantly threatened from outside by a loss of meaning, against which philological techniques must protect it:

La notion de texte [dans cette acception classique] implique que le message écrit est articulé comme le signe ... Le signe classique est une unité close, dont la fermeture arrête le sens, l'empêche de trembler, de se dédoubler, de divaguer; de même pour le texte classique: il ferme l'oeuvre, l'enchaîne à sa lettre, la rive à son signifié. Il engage donc à deux types d'opérations, destinées l'une et l'autre à réparer les brèches que mille causes (historiques, matérielles ou humaines) peuvent ouvrir dans l'intégrité du signe. Ces deux opérations sont la restitution de l'interprétation ... De la 'restitution' du signifiant, on passe naturellement à l'interprétation canonique du signifié.

(Barthes, [1973c] 1994c, 1677-1678)

['The notion of text [in this classic acceptation] implies that the written message is articulated like the sign ... The classical sign is a sealed unit, whose closure arrests meaning, prevents it from trembling or becoming double, or wandering. The same goes for the classical text: it closes the work, chains it to its letter, rivets it to its signified. It thus commits us to two types of operation, both intended to repair the holes which a thousand causes (historical, material, human causes) can punch in the integrity of the sign. These two operations are those of restoration and interpretation ... From the 'restitution' of the signifier one passes naturally to the canonical interpretation of the signified.'] (Barthes, [1973d] 1981, 33)

Barthes argues here that the 'classical' text is constructed as an object that has both a (single, correct, true) material form and a (single, correct, true) meaning. This form and this meaning are mutually determining, and it is the task of philology to maintain or rediscover this form and this meaning. However, this text is always at risk from external forces that can 'punch [holes] in the integrity 
of the sign'; it thus needs to be protected and restored by the techniques of philology. These operations involve closing the text, arresting meaning, and preventing it from 'becoming double or wandering' - the principle behind Steiner's emphasis on the importance of evading the risk of homonymic (doubled, wandering) reading.

Here, Barthes implicitly juxtaposes the philological text (whose integrity is threatened from the outside) with the semiological text, constituted from within by the very forces of doubleness and wandering that philology seeks to externalize and disavow. The question of whether doubleness and drift are internal or external to the text (and indeed the sign) remains implicit in Barthes's essay, but had been made explicit two years earlier in an essay by his Tel Quel colleague Jacques Derrida in Signature événement contexte ['Signature Event Context']:

La généralité du risque [des infélicités] ... entoure-t-elle le langage comme une sorte de fossé, de lieu de perdition externe dans lequel la locution pourrait toujours ne pas sortir, qu'elle pourrait éviter en restant chez soi ...? Ou bien ce risque est-il au contraire sa condition de possibilité interne et positive? ce dehors son dedans? la force même et la loi de son surgissement? (Derrida, [1971a] 1972, 387; emphasis in original)

['Does the generality of the risk [of infelicity] ... surround language like a kind of ditch, a place of external perdition into which locution might never venture, that it might avoid by remaining at home ... ? Or indeed is this risk, on the contrary, its internal and positive condition of possibility? this outside its inside? the very force and law of its emergence?']

(Derrida, 1982, 325)

In the same essay, Derrida, echoing Barthes's emphasis on the 'wandering' of meaning, argues that:

il appartient au signe d'être en droit lisible ... même si je ne sais pas ce que son prétendu auteur-scripteur a voulu dire en conscience et en intention au moment où il l'a écrit, c'est-à-dire abandonné à sa dérive essentielle.

(Derrida, [1971a] 1972, 377)

['by all rights, it belongs to the sign to be legible ... even if I do not know what its alleged author-scriptor meant consciously and intentionally at the moment he wrote it, that is abandoned it to its essential drifting.']

(Derrida, 1982, 317)

Where classical philology constructed the text as fixed, for both Derrida and Barthes its essential properties are wandering, drifting, trembling, and doubleness. The risks to meaning that les philologues attempt to ward off are, then, precisely what constitute the text in the first place; their work is only the belated attempt to close, arrest, contain, and resist the dérive essentielle ['essential 
drifting'] of writing and the disseminative force of textuality. The text that functions as the 'origin' of meaning is produced as origin and as legitimating ground by a specific set of philological practices, of which it is, however, not the cause but the effect.

This arrest of meaning, Barthes explains, is achieved through the insistence on a specific set of rules for reading, which are designed to produce (Barthes's philologists would say 'maintain' or 'rediscover') a single meaning:

Le texte est le nom de l'oeuvre, en tant qu'elle est habitée par un sens et un seul, un sens 'vrai', un sens définitif; il est cet 'instrument' scientifique qui définit autoritairement les règles d'une lecture éternelle.

(Barthes, [1973c] 1994c, 1678)

['The [philological] text is the name of the work in so far as it is inhabited by one, and only one, meaning, a 'true' meaning, a 'definitive' meaning. It is that scientific 'instrument' which defines in an authoritarian way the rules of an eternal reading.'] (Barthes, [1973d] 1981, 33)

The problem is not that the philological 'lecture éternelle' requires rules; it is impossible to read without rules, as Barthes demonstrates in his 1970 essay 'Écrire la lecture' ['Writing Reading'] (Barthes, [1970b] 1989b, 31; Barthes, [1970a] 1994a, 962). Rather, the problem arises when one does not acknowledge these 'rules' as ludic. In the classical universe of the philological text, the rules for reading are instead 'authoritarian,' that is, complicit with extratextual (institutional, ideological) forms of authority. These non-ludic, authoritarian rules have two functions. First, they close the text on a singular meaning; second, they erase any signs that this closing is an intervention in the textual field, instead constructing closure as an 'ontologically grounded formal property' of the text (Mowitt, 1992, 8).

The question of the text's closure is precisely the point of difference between Barthes and Steiner. As we have seen, Steiner attempts to do away with all extratextual factors: he locates the meaning of a text securely in the text itself, eradicating context and intertext and arguing that sense making merely requires technical literacy skills in a given language (no matter how complicated and problematized the idea of 'language' might be). At this point, a paradox arises: in order to read the text, the whole text and nothing but the text, Steiner's reader must constantly go beyond the text itself. His 'true reader is a dictionary addict' (Steiner, 1975, 24): she cannot simply glean the meaning of the text from the text itself, but must spend the majority of her time looking away from the text, at other texts. 'A demanding reader of mid-eighteenth-century verse,' Steiner tells us, 'will often find himself referring to the Royal Horticultural Society's Dictionary of Gardening' (Steiner, 1975, 24).

Steiner's reader here begins to look surprisingly like Barthes's (or even like Barthes). Barthes asks us, in 'Ecrire la lecture,' 'Ne vous est-il pas arrivé de lire en 
levant la tête?' ['Haven't you ever happened to read while looking up from your book?'] (Barthes, [1970b] 1989b, 29; Barthes, [1970a] 1994a, 961). He argues that:

[la] logique du symbole ... n'est pas déductive mais associative: elle associe au texte matériel ... d'autres idées, d'autres images, d'autres significations. 'Le texte, le texte seul', nous dit-on, mais le texte seul ça n'existe pas: il y a immédiatement dans cette nouvelle, ce roman, ce poème que je lis, un supplément de sens, dont ni le dictionnaire ni la grammaire ne peuvent rendre compte. (Barthes, [1970a] 1994a, 962)

['(the) logic of the symbol ... is not deductive but associative: it associates with the material text ... other ideas, other images, other significations. 'The text, only the text,' we are told, but 'only-the-text' does not exist: there is immediately in this tale, this novel, this poem I am reading, a supplement of meaning for which neither dictionary nor grammar can account.']

(Barthes, [1970b] 1989b, 30-31, emphasis original)

Le texte seul, ça n'existe pas: reading can only take place if the text is opened onto contextual and intertextual associations; the boundary of the text cannot be determined from the formal properties of the text as verbal artifact. Even Steiner, who at first seemed to be attempting to do away with Barthes's supplément $d u$ sens, has to admit as much when his reader must look away from the text in order to find out what is in it.

The question then becomes how to decide which associations, which 'other ideas, other images, other significations,' should be used in making sense of the text. Steiner attempts to close down this question by troping all contextual and intertextual associations as dictionaries, so that the fixity of the classic sign constrains the disseminative force of the symbol ('la force explosive du texte, son energie digressive' ['the text's explosive force, its digressive energy'] [Barthes, [1970b] 1989b, 30; Barthes, [1970a] 1994a, 962]). But if the possibility of homonymic reading is not a risk that surrounds language, but rather the condition of possibility of reading itself, then Steiner's approach does not resolve the question. Instead, it opens a new set of questions. If the 'language' (in the expanded sense that both Steiner and Barthes give the term, although in different ways) in which a text is written is not simply given by the text itself - as we have seen it is not - then on what basis do we decide what language to read in?

What Barthes (sometimes) calls 'philology' is a set of conventional reading practices that seek to protect the single, canonical meaning of a text from the risks of drift and doubleness: or rather, that seek to disavow the irreducible and properly textual forces of drift and doubleness, and to legitimate themselves with reference to the non-existent entity le texte seul ['only-the-text']. What Barthes opposes under the name 'philology' is a theory of the text that disingenuously seeks to locate in the 'text itself,' as the formal and ontological property of closure, what is in fact a set of institutional, social, and ideological practices for making sense of texts. 
4 See, for example, 'La division des langages' ([1973e] 1984a) and 'Pourquoi j’aime Benveniste' ([1974] 1984b).
But it is only sometimes that Barthes uses the name 'philology' for these practices of closure. Indeed, he opens 'Texte (théorie du)' with the question Qu'est-ce qu'un texte, pour l'opinion courante? ['What is a text, for current opinion?'] (Barthes, [1973d] 1981, 32; Barthes, [1973c] 1994c, 1677). This 'current opinion' - myth or ideology - is much more often opposed to the semiological text. Philology opposes the semiological text only insofar as it is complicit with ideology: indeed, as Sarah Kay has pointed out, in this period Barthes avails himself enthusiastically of many of the traditional resources of philology, notably historical linguistics (Kay, 2013). ${ }^{4}$

We might well ask, then, whether everything that goes by the name of 'philology' is necessarily ideological. In the climate of the political hostility to philology traced by Carolyn Dinshaw in Getting Medieval (Dinshaw, 1999, 173-182), the claim that the 'labor intensive, preindustrial, artisanal craft' of philology (Pollock, 2009, 945) is complicit with the ideology of contemporary capitalism looks increasingly less sustainable. Michelle Warren, similarly, makes a convincing case for the detailed, attentive readings of philology as 'an active participant in the disruption of hegemonic discourses' (Warren, 2003, 23): philological techniques can be used against the 'authoritarian rules', which would disingenuously close down the text. In this light, Pollock's 'philology in three dimensions' clearly has as its object not l'ancien texte des philologues but Barthes's semiological text. Like Barthes, Pollock critiques the ideology of the singular meaning' (Pollock, 2009, 955) and argues that one 'plane' of philological reading must be the subjectivity, and the pleasure, of the reader: in making sense of texts, we must 'try to make sense of this "pleasure," or whatever it [is] the work afford[s] me' (Pollock, 2014; emphasis added). Subjectivity and pleasure are the very dimensions of reading that Barthes opposes to the philological text in 'Texte (théorie du)' via the binary distinction between 'signification' (on the side of philology) and 'signifiance' (on the side of semiology). 'Signifiance' is defined by its relation to jouissance - pleasure, bliss - and by subjective engagement with the text: '[il] place le sujet (de l'écrivain, du lecteur) dans le texte' ['it puts the (writing or reading) subject into the text'] (Barthes, [1973d] 1981, 38; Barthes, [1973c] 1994c, 1692).

Philology, at least as practiced by critical philologists, post-philologists, or liberation philologists like Warren, Dinshaw, Pollock and the other contributors to this issue, has transformed along with its object, the text. Just as for Barthes the text becomes an objet nouveau ['new object'] while retaining the same name, the science nouvelle ['new science'] that Barthes develops can and perhaps must be called by its old name: philology. Indeed, in Plaisir $d u$ Texte - published the same year as Texte (théorie $d u$ ) - Barthes positions himself precisely as a philologist, so long as that term is read homonymically in Greek and not in French. He writes of the Société des Amis du Texte that:

ses membres n'auraient rien en commun (car il n'y a pas forcément accord sur les textes du plaisir), sinon leurs ennemis: casse-pieds de toutes sortes, qui décrètent la forclusion du texte et de son plaisir ... Une telle société 
n'aurait pas de lieu, ne pourrait se mouvoir qu'en pleine atopie; ce serait pourtant une sorte de phalanstère, car les contradictions y seraient reconnues (et donc restreints les risques d'imposture idéologique), la différence y serait observée et le conflit frappé d'insignifiance (étant improducteur de plaisir). (Barthes, 1973a, 26-27)

['Its members would have nothing in common (for there is no necessary agreement on the texts of pleasure) but their enemies: fools of all kinds, who decree foreclosure of the text and of its pleasure ... Such a society would have no site, would function only in total atopia; yet it would be a kind of phalanstery, for in it contradictions would be acknowledged (and the risks of ideological imposture thereby restricted), difference would be observed, and conflict rendered insignificant (being unproductive of pleasure).']

(Barthes, [1973b] 1975, 14-15)

The Friends of the Text are united not by a shared canon of texts or languages, but by their mode of approach to the text, troped as 'friendship' [philia]. The text that they befriend is not the closed text of current opinion, but the text of pleasure and of non-conflictual difference (precisely the text that Pollock befriends). And the Friends of the Text are, of course, philologists, as Werner Hamacher reminds us in his 95 Thesen zur Philologie: 'Ihr Name besagt nicht Wissen vom logos ... sondern: Zuneigung, Freundschaft, Liebe zu ihm' ['its [philology's] name does not signify knowledge of the logos ... but affection for, friendship with, inclination to it'] (Hamacher, 2009, 26; Hamacher, 2010, 9).

I opened this paper with an example of reading in the 'wrong' language, Hélias's reading of the Latin Mass in Breton, as a creative and productive practice of making sense of a text. I argued that this practice succeeded in constructing the 'mere sounds' of the Latin mass as a text, and that, far from being an example of a simple misunderstanding 'lower in the philological scale of value than other' interpretations (Pollock, in this volume), it is a key to understanding what it means to make sense - to philologize, in the expanded sense that opposes the foreclosure of a text by authoritarian rules or ideology.

Of course, reading in the 'wrong' language is not necessarily more productive, more creative, more anti-authoritarian, than reading in the 'right' language: to argue so would be to retain too much of Steiner's conception of the text. As a counterpart to Hélias's reading practice, therefore, I turn now to a short story from 1974 - that is, from the historical moment with which this essay is concerned. The story, Ursula Le Guin's 'The Author of the Acacia Seeds,' investigates and practices the transformation of the text: it is a beautiful and rigorous staging of the liberatory possibilities of reading in the 'right' languages.

Le Guin's story presents itself as a piece of academic writing: its subtitle is 'And Other Extracts from the Journal of the Association of Therolinguists.' There are three extracts in total: 'MS found in an Anthill,' 'Announcement of an Expedition,' and 'Editorial, by the President of the Therolinguistics Association.' The extracts 
move us through a carefully gradated series of non-human languages - hence 'therolinguists,' those who read the languages of beasts (Greek $\theta \dot{\eta} \rho$, beast). The story presents impeccably philological readings of these texts by immersing us in a new, fictive, future world. As readers, we are required to construct imaginatively a social, cultural, and historical context in which its claims might make sense. In this way, Le Guin's story not only gestures toward but instantiates a common ground between, on the one hand, the difficult, attentive, detailed work of reading in an unfamiliar language, and, on the other, the creative and imaginative work of making sense of texts.

The first extract concerns the interpretation of an Ant text 'written in touch-gland exudation on degerminated acacia seeds' (Le Guin, [1974] 1983, 3). This text, although profoundly alien, is at least 'written' in a relatively familiar way: it is the product of an individual author and it exists as a specific arrangement of markings on material objects (the acacia seeds). Moreover, although it presents the difficulties of interpretation, these are of a relatively familiar kind. The debate in this extract is over the valency of the word 'up' in the phrase 'Up with the Queen!' on Seed 31: 'to us, "up" is a "good" direction ... Not necessarily so to an ant' (Le Guin, [1974] 1983, 5).

In the second extract, we move to languages written by groups, rather than by single authors, and, even more strangely to us, 'written' in movement through air and water ('in wings, neck, and air') rather than in durable markings on a solid surface:

It was Professor Duby who, by pointing out the remote affiliation of the script with Low Greylag, made possible the first tentative glossary of Penguin ... Indeed, it seemed strange that a script written almost entirely in wings, neck and air should prove the key to the poetry of short-necked, flipper-winged water-writers. But we should not have found it so strange if we had kept in mind the fact that penguins are, despite all evidence to the contrary, birds ... that they do not swim but fly in water.

$$
\text { (Le Guin, [1974] 1983, 6) }
$$

This extract describes 'the difficulty of translation' in relation to the 'group kinetic texts' written by penguins (Le Guin, [1974] 1983, 6-7).

The final extract, the Editorial, goes yet further, sketching the difficulties, and speculating about the possibilities, of learning how to read scripts and languages beyond the animal: 'We have not yet lifted our eyes to the vaster horizons before us. We have not faced the almost terrifying challenge of the Plant' (Le Guin, [1974] 1983, 9). Terrifying, because 'if a non-communicative, vegetative art exists, we must rethink the very elements of our science, and learn a whole new set of techniques' (Le Guin, [1974] 1983, 10). The President ends her Editorial with a speculative fantasy about the first phytolinguists 'hik[ing] on up to read the newly deciphered lyrics of the lichen on the north face of Pike's Peak,' and asks:

And with them, or after them, may there not come that even bolder adventurer - the geolinguist, who, ignoring the delicate, transient lyrics of 
the lichen, will read beneath it the still less communicative, still more passive, wholly atemporal, cold, volcanic poetry of the rocks: each one a word spoken, how long ago, by the earth itself, in the immense solitude, the immenser community, of space. (Le Guin, [1974] 1983, 11)

Le Guin's story, like the classic texts of science fiction, casts the future as a heroic exploration of the non-human world: but it casts that exploration in philological terms. No extra-terrestrial species, languages, or locations are invoked; no new technologies are mentioned. We see 'the underwater motion-picture camera,' 'time-lapse photography,' and a hiker with a rucksack (Le Guin, [1974] 1983, 5, 6, 10), none of which are recent even in 1974. The Editorial links the passing of time to human progress, but this progress is measured solely by the achievements of therolinguists and their imagined future counterparts, phytolinguists, and geolinguists. The science-fictional adventure and the narrative of human history are shown to consist in learning to be better readers of texts, and being a better reader consists of being a less ethnocentric reader. A better reader is more open to otherness, more able to recognize, and appreciate texts with which she does not share common assumptions, more able to read in ways that resist the 'authoritarian rules' of ideology, ethnocentrism, anthropocentrism, and paronthocentrism (present-centeredness, 'the historical equivalent of phallocentrism and ethnocentrism,' which 'undermines the possibility of understanding the present's historical other: the past' [Bal, 1999, 19]). Le Guin's story stages the ways in which the resources of philology can be put, not to ideological, but to utopian ends.

Barthes writes that the Society of the Friends of the Text would or could exist only in total atopia - une sorte de phalanstère ('a sort of phalanstery'), that is, the sort of ideal, co-operative community imagined by Charles Fourier (Barthes, 1973a, 26-27; Barthes, [1973b] 1975, 14-15). This atopia, then, is also a utopia. The theory of textuality elaborated by the Tel Quel group, as Mowitt shows, has a necessary relationship to utopia. If 'the closure of the text is coordinated with the socially constructed perception of its limits' (Mowitt, 1992, 8), and if philology is what resists the text's foreclosure - that is, resists, questions, and repositions the text's socially constructed boundary - then philology opens the text onto 'what as yet, has no place within the social' (Mowitt, 1992, 17). Le Guin stages precisely this philological operation, as her therolinguists refuse to accept the socially constructed perception of the limits of textuality. They practice a future-oriented, utopian philology, accommodating that which has no place within the social (the languages, texts, and art of insects, birds, plants, and minerals); they insist on the possibility of change in the social institutions and cultural assumptions according to which we read.

These changes become possible, Le Guin's story tells us, by learning to see familiar objects as texts. Although they appear at first sight to occupy opposite ends of a philological spectrum, Le Guin's therolinguists meet here with Hélias's Breton children. Both groups of readers succeed in making sense of objects which 
a linguistic barrier has transformed into meaningless things: the words of Latin mass, the arrangement of degerminated acacia seeds, the movement of penguin necks and wings through air, the lichen on Pike's Peak, the rocks of the peak itself. Both Hélias's children and Le Guin's therolinguists succeed in making sense of texts, and both do so by refusing to obey certain ethnocentric/anthropocentric/ paronthocentric rules that would definitively foreclose these texts and their pleasures by rendering them meaningless. Both, then, are philologists: Hélias's Breton congregation and Le Guin's Association of Therolinguists are instantiations of the Society of the Friends of the Text.

\section{Acknowledgement}

With thanks to Michelle Warren for inviting me to contribute to this volume and for a generous and perceptive edit, and to Sarah Kay for her invaluable response to a draft version of this paper at the conference 'Philology/Humanism' at Dartmouth College in October 2013.

\section{About the Author}

Ika Willis is Lecturer in English Literatures at the University of Wollongong. She is interested in a wide range of theories of reading, reception, and textuality, and has published on texts from Vergil's Georgics to Harry Potter fan fiction (E-mail: ikaw@uow.edu.au).

\section{References}

Bal, M. 1999. Quoting Caravaggio. Chicago, IL: University of Chicago Press.

Barthes, R. 1973a. Le Plaisir du Texte. Paris, France: Éditions de Seuil.

Barthes, R. [1973b] 1975. The Pleasure of the Text, trans. R. Miller. New York: Hill and Wang.

Barthes, R. [1973d] 1981. Theory of the Text. In Untying the Text: A Post-Structuralist Reader, ed. R. Young, trans. I. McLeod, 31-47. London: Routledge and Kegan Paul.

Barthes, R. [1973e] 1984a. La division des langages. In Le bruissement de la langue, 113-126. Paris, France: Éditions de Seuil.

Barthes, R. [1974] 1984b. Pourquoi j'aime Benveniste. In Le bruissement de la langue, 191-196. Paris, France: Éditions de Seuil.

Barthes, R. [1971b] 1989a. From Work to Text. In The Rustle of Language, trans. R. Howard, 56-64. Berkeley, CA: University of California Press.

Barthes, R. [1970b] 1989b. Writing Reading. In The Rustle of Language, trans. R. Howard, 29-32. Berkeley, CA: University of California Press.

Barthes, R. [1970a] 1994a. Écrire la lecture. In Oeuvres complètes, ed. É. Marty, 2: 961-963. Paris, France: Éditions de Seuil. 
Barthes, R. [1971a] 1994b. De l'oeuvre au texte. In Oeuvres complètes, ed. É. Marty, 2: 1211-1217. Paris, France: Éditions de Seuil.

Barthes, R. [1973c] 1994c. Texte (théorie du). In Oeuvres complètes, ed. É. Marty, 2: 1677-1689. Paris, France: Éditions de Seuil.

Bauman, Z. 1978. Hermeneutics and Social Science: Approaches to Understanding. London: Routledge.

Borges, J.L. 1962. Pierre Menard, Author of the Quixote. In Ficciones, trans. A. Bonner, 45-55. New York: Grove Press.

Borges, J.L. [1939] 1999. Pierre Menard, autor del Quijote. In Ficciones, 41-55. Madrid, Spain: Alianza Editorial.

De Man, P. 1986. The Return to Philology. In The Resistance to Theory, 21-26. Minneapolis, MN: University of Minnesota Press.

Derrida, J. [1971a] 1972. Signature événement contexte. In Marges de la philosophie, 365-393. Paris, France: Éditions de Minuit.

Derrida, J. 1982. Signature Event Context. In Margins of Philosophy, trans. A. Bass, 307-330. Brighton, UK: Harvester Press.

Dinshaw, C. 1999. Getting Medieval: Sexualities and Communities, Pre- and Post-Modern. Durham, NC: Duke University Press.

Ducrot, O. and T. Todorov. 1972. Dictionnaire encyclopédique des sciences du langage. Paris, France: Éditions de Seuil.

Hamacher, W. 2009. 95 Theses on Philology, trans. C. Diehl. Diacritics 20(1): 25-44.

Hamacher, W. 2010. 95 Thesen zur Philologie. Frankfurt am Main, Germany: Engeler.

Hélias, P.J. [1975] 1995. Le cheval d'orgeuil: mémoires d'un Breton du pays bigouden. Paris, France: Plon.

Kay, S. 2013. Response to Ika Willis. Remarks delivered at conference, 'Mirage/Time: Philology and Post/Humanism,' October 19. Hanover, NH: Dartmouth College.

Le Guin, U.K. [1974] 1983. The Author of the Acacia Seeds, and Other Extracts from the Journal of the Association of Therolinguistics. In The Compass Rose, 3-11. Toronto and New York: Bantam. Transcribed by M. Webb at Interconnected, http://interconnected .org/home/more/2007/03/acacia-seeds.html.

Martindale, C. 1993. Redeeming the Text: Latin Poetry and the Aesthetics of Reception. Cambridge, UK: Cambridge University Press.

Mowitt, J. 1992. Text: The Genealogy of an Antidisciplinary Object. Durham, NC: Duke University Press.

Pollock, S. 2009. Future Philology? The Fate of a Soft Science in a Hard World. Critical Inquiry 35(4): 931-961.

Steiner, G. 1975. Understanding as Translation. In After Babel: Aspects of Language and Translation, 1-31. Oxford: Oxford University Press.

Waquet, F. 1998. Le Latin ou l'émpire d'une signe. Paris, France: Éditions Albin Michel.

Waquet, F. 2001. Latin, or the Empire of a Sign from the Sixteenth to the Twentieth Centuries, trans. J. Howe. London and New York: Verso.

Warren, M.R. 2003. Post-Philology. In Postcolonial Moves: Medieval Through Modern, eds. P.C. Ingham and M.R. Warren, 19-45. New York: Palgrave Macmillan. 